\title{
Transitioning to Intellectual Property: How can the WTO integrate Least- Developed Countries into TRIPS?
}

\section{Arno Hold I Bryan Christopher Mercurio*}

\begin{abstract}
Despite the looming expiration of the extended transition period under Article 66.1 of the Agreement on Trade-related Aspects of Intellectual Property Rights (TRIPS) on 1 J uly 2013, most least-developed countries (LDCs) have not made significant progress in implementing the TRIPS Agreement. WTO Members have accepted this reality and a re currently considering a nother extension of the transition period. In the coming months, the disc ussions in the TRIPS Council on how to meaningfully integra te the poorest countries into the intemational system for the protection of intellectual property will intensify. This working paper seeks to assist these discussions by first providing a comprehensive legal analysis of the various rights and obligations for LDCs, developed country Members and intemational organizations under the transitional arrangements in the TRIPS Agreement, subsequent WTO legislation and in particular the TRIPS Council Decision of 2005. Next, the authors identify several major shortcomings in the priority needs assessment process as set out in the TRIPS C ouncil Decision of 2005 and argue that there is a strong need for greater coordination on the national and multilateral level in order to unlock increased technical and financial assistance for LDCs. The working paper then concludes that an unconditional second extension of the transition period would be detrimental to LDC's implementation of TRIPS and might also undermine the credibility of the entire multilateral IP regime. Instead, the authors propose a variety of alternative avenues to more successfully integrate LDC s into the international IP system.
\end{abstract}

* Arno Hold is a Research Fellow at the World Trade Institute (WTI) of the University of Bem and the Director of the WTI/CUHK Summer Programme on Intellectual Property. Bryan Christopher Merc urio is a Professor of Law and Associate Dean (Research) at The Chinese University of Hong Kong (CUHK). The views expressed here shall neither be attributed to the institutions to which the authors are affiliated nor to their Member States. Research for this paper was partly funded by the Swiss National Science Foundation under a grant to the National Centre of Competence in Research on Trade Regulation, based at the World Trade Institute of the University of Bem, Switzerland. 


\section{Table of Contents}

I. Introduction

II. Rights and obligations of the WTO Members with regard to the LDCs' TRIPS implementation.

1. LDCs' role in the TRIPS negotiations

2. Transitional arrangements contained in Article 65 of TRIPS ..................................... 7

3. Transition periods for LDCs contained in Article 66.1 of TRIPS................................ 8

4. Technical and financial assistance (Article 67 TRIPS) ......................................... 9

5. The extension of the $L D C$ transition period for $L D C$ s................................................ 9

III. State of play approaching the end of the first extension of the transition period for LDCs.

1. Achievements and shortcomings of the priority needs assessment process

2. Impact on the provision of technical and financial assistance by developed

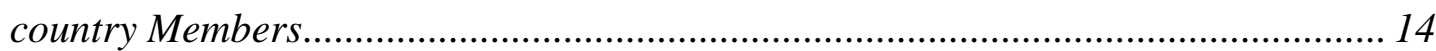

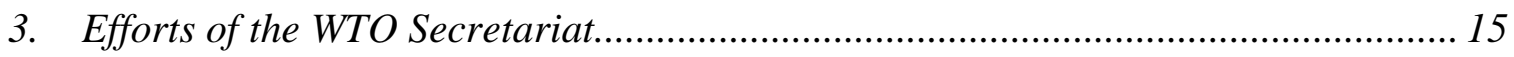

4. The need for enhanced coordination on various levels in order to make the priority needs assessment process work.......................................................................... 17

5. The Enhanced Integrated Framework (EIF) and Aid-for-Trade (AfT) as

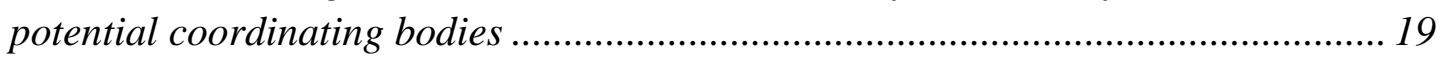

6. Towards a second extension of the transition period for LDCs ................................ 20

IV. The drawbacks of an unconditional second extension of the transition period ......... 21

1. Why granting an unconditional second extension of the transition period might be detrimental to the implementation of TRIPS by LDCs? ....................................... 21

2. Assessing the consequences if no extension or only a very short extension of the transition period were to be granted.

V. Potential alternatives to an unconditional second extension of the transition period

1. Granting a moratorium on claims being brought against LDCs under TRIPS ......... 23

2. Introducing conditions for a second extension of the transition period 24

3. Applying a more gradual and development-oriented concept of TRIPS implementation for LDCs.

4. Identifying additional incentives for LDCs and developed countries to cooperate more actively towards LDCs' integration in the global IP system.

VI. Conclusion

References. 


\title{
Transitioning to Intellectual Property: How can the WTO integrate Least-Developed Countries into TRIPS?
}

\author{
ARNO HOLD AND BRYAN CHRISTOPHER MERCURIO *
}

Despite the looming expiration of the extended transition period under Article 66.1 of the Agreement on Trade-related Aspects of Intellectual Property Rights (TRIPS) on 1 July 2013, most least-developed countries (LDCs) have not made significant progress in implementing the TRIPS Agreement. WTO Members have accepted this reality and are currently considering another extension of the transition period. In the coming months, the discussions in the TRIPS Council on how to meaningfully integrate the poorest countries into the international system for the protection of intellectual property will intensify. This working paper seeks to assist these discussions by first providing a comprehensive legal analysis of the various rights and obligations for LDCs, developed country Members and international organizations under the transitional arrangements in the TRIPS Agreement, subsequent WTO legislation and in particular the TRIPS Council Decision of 2005. Next, the authors identify several major shortcomings in the priority needs assessment process as set out in the TRIPS Council Decision of 2005 and argue that there is a strong need for greater coordination on the national and multilateral level in order to unlock increased technical and financial assistance for LDCs. The working paper then concludes that an unconditional second extension of the transition period would be detrimental to LDC's implementation of TRIPS and might also undermine the credibility of the entire multilateral IP regime. Instead, the authors propose a variety of alternative avenues to more successfully integrate LDCs into the international IP system.

\section{Introduction}

Concluded as part of the Uruguay Round of trade negotiations which created the World Trade Organization (WTO), the Agreement on Trade-related Aspects of Intellectual Property Rights (TRIPS) sets out the international framework for protecting intellectual property rights (IPRs). In addition to requiring certain minimum standards, respect for core principles such as national treatment and most-favoured nation and containing several procedural and administrative requirements, TRIPS also provided least-developed country (LDC) Members of the WTO with a transition period of 10 years to apply the bulk of their new obligations (through Article 66.1 of TRIPS). By 2005, however, most LDCs had neither managed to implement TRIPS nor taken the necessary steps required to strengthen their protection and

\footnotetext{
* Arno Hold is a Research Fellow at the World Trade Institute (WTI) of the University of Bern and the Director of the WTI/CUHK Summer Programme on Intellectual Property. Bryan Christopher Mercurio is a Professor of Law and Associate Dean (Research) at The Chinese University of Hong Kong (CUHK). The views expressed here shall neither be attributed to the institutions to which the authors are affiliated nor to their Member States. Research for this paper was partly funded by the Swiss National Science Foundation under a grant to the National Centre of Competence in Research on Trade Regulation, based at the World Trade Institute of the University of Bern, Switzerland.
} 
enforcement of IPRs as the Agreement required. Thus, on 29 November 2005 the WTO/TRIPS Council extended the original TRIPS Article 66.1 transition period for the implementation of TRIPS for LDCs from 1 January 2006 to 1 July 2013. ${ }^{1}$ The same WTO Decision called on LDCs to provide to the TRIPS Council as much information as possible on their individual priority needs for technical and financial assistance from developed country Members. In other words, the Decision asked LDCs to prioritize their requirements, needs and desires and communicate them to the TRIPS Council in order to facilitate technical and financial assistance from developed country Members of the WTO. As of September 2012, only 6 LDCs - Uganda, Sierra Leone, Bangladesh, Rwanda, Tanzania, and Senegal - have tabled such individual priority needs assessments. Therefore, 25 of the 31 LDC Members of the WTO have yet to submit any substantial response to the TRIPS Council.

With the implementation deadline of 1 July 2013 looming, Ministers at the Eighth Ministerial Conference (December 2011) adopted a Decision inviting the TRIPS Council to consider a second extension of the transitional implementation period. Since that Decision, discussions have continued at the TRIPS Council on how to meaningfully integrate the poorest countries into the international system for the protection of IPRs. These discussions are expected to conclude shortly before the expiration of the first extension of the transition period.

The objective of this working paper is to contribute to this debate by examining the rights and obligations of all parties involved, by identifying the major challenges of the current setting and by formulating recommendations on how to resolve the deadlock of LDCs' implementation of TRIPS.

The working paper is structured as follows:

Section II provides a legal analysis of the various rights and obligations for LDCs, developed country Members and international organizations under the transitional arrangements contained in TRIPS as well as all subsequent WTO Decisions, in particular the TRIPS Council Decision of 2005.

Section III assesses the ramifications of the 2005 TRIPS Council Decision that led to the priority needs assessment process and provides an overview of the state of play in the TRIPS Council as we approach the expiration of the extended transition period granted to LDCs to implement the TRIPS Agreement. Furthermore, Section III identifies the major achievements and shortcomings of the priority needs assessment process and argues that there is a strong need for increased multilateral coordination on various levels in order to unlock comprehensive and effective technical and financial assistance for LDCs in the field of IPRs under Article 67 of TRIPS.

Section IV explores why an unconditional second extension of the transition period for LDCs may lead to an unfavourable outcome for both LDCs and developed countries. It also sets out potential alternatives to an unconditional second extension and offers recommendations on how to best resolve the deadlock in the LDCs' TRIPS implementation process.

Section V concludes with a brief summary and the implications of our findings for the ongoing debate on how to better integrate the LDCs into the global system for the protection of intellectual property.

\footnotetext{
${ }^{1}$ World Trade Organization, Extension of the transition period under Article 66.1 for least-developed country Members, Decision of the Council for TRIPS of 29 November 2005, 30 November 2005 (IP/C/40).
} 


\section{Rights and obligations of the WTO Members with regard to the LDCs' TRIPS implementation}

\section{LDCs' role in the TRIPS negotiations}

At the time of the negotiation of TRIPS, most industrialized countries had long-established comprehensive domestic legislation in the field of IPRs. These same countries had also negotiated, signed and ratified several World Intellectual Property Organization (WIPO) Conventions and Treaties. Thus, industrialized countries had a strong framework of IPRs in both the domestic and the international sphere. By contrast, many developing countries and most LDCs ${ }^{2}$ had neither a comprehensive domestic system for the protection and enforcement of IPRs nor much experience in negotiating international conventions and treaties on IPRs. It is thus not surprising that a group of industrialized countries were not only the demandeurs but also largely dictated the shape of the negotiating text and of the final text.

More specifically, even when seeking to include IP as a negotiating topic in the Uruguay Round of trade negotiations, the US and other industrialized countries used the carrot and stick approach to achieve the objective of strengthening the global system of IP protection. The carrots for negotiating and agreeing to the inclusion of IP in the Uruguay Round were concessions in other trade areas, notably increased access to developed country agriculture and textiles markets. ${ }^{3}$ Developing countries were also granted several important TRIPsrelated concessions, most notably deferred implementation of the substantial portions of the agreement and in promises of technology transfer and assistance. ${ }^{4}$ The stick came in the form of a threat of continued unilateral action ${ }^{5}$ that could potentially threaten the trade and aid

\footnotetext{
${ }^{2}$ The categorization of countries as developed or developing has been a matter of uncontested self-selection; however, this is not necessarily automatically accepted in in the WTO context. According to Article XI:2 supra note 6 of the Marrakesh Agreement Establishing the World Trade Organization, the WTO recognizes those countries as least-developed which have been designated as such by the United Nations. The United Nations Economic and Social Council (ECOSOC) reviews the list every three years according to the following three criteria: low per capita income, weak human resources, and high economic vulnerability. Of the 48 LDCs currently listed, to date, the following 31 are WTO Members: Angola, Bangladesh, Benin, Burkina Faso, Burundi, Cambodia, Central African Republic, Chad, Democratic Republic of the Congo, Djibouti, Gambia, Guinea, Guinea Bissau, Haiti, Lesotho, Madagascar, Malawi, Mali, Mauritania, Mozambique, Myanmar, Nepal, Niger, Rwanda, Senegal, Sierra Leone, Solomon Islands, Tanzania, Togo, Uganda, and Zambia. Furthermore, 12 LDCs are currently negotiating their accession the WTO: Afghanistan, Bhutan, Comoros, Equatorial Guinea, Ethiopia, Laos, Liberia, Sao Tomé \& Principe, Samoa, Sudan, Vanuatu, and Yemen.

${ }^{3}$ See e.g. Mercurio, Bryan Christopher (2010), 'Reconceptualising the Debate on Intellectual Property Rights and Economic Development’ (2010) 3(1) The Law and Development Review, pp. 65-107; Durán, Esperanza and Constantine Michalopoulos (1999), 'Intellectual Property Rights and Developing Countries in the WTO Millennium Round’, 2 Journal of World Intellectual Property 6 (1999), pp. 853-874; Christopher May and Susan K. Sell, Intellectual Property Rights: A Critical History (Lynne Rienner, 2005).

${ }^{4}$ The benefits of the concessions are subject to debate. See, i.e., Matthews, Duncan and Munoz-Tellez, Viviana (2006), 'Bilateral Technical Assistance and TRIPS: the United States, Japan and the European Communities in Comparative Perspective’, 9 Journal of World Intellectual Property 6 (2006), p. 629; Trainer, Timothy P. (2008), 'Intellectual Property Enforcement: A Reality Gap (Insufficient Assistance, Ineffective Implementation)?’, 8 John Marshall Review of Intellectual Property Law 1 (2008), p. 47.

${ }^{5}$ For instance, the US began unilaterally enforcing IPRs by virtue of the authority of the United States Trade Representative (USTR) under Section 301 US Trade Act of 1974, in which the US initiated litigation against other countries in the US Court of International Trade (USITC) under its domestic unfair trade practices laws, even though the respondent countries had not violated any international agreement. The US filed cases against
} 
flowing from developed countries to the developing world. ${ }^{6}$

After initial opposition, objections from developing countries waned and attention turned to negotiating the agreement. ${ }^{7}$ The potential benefits of the sectoral trade-offs appeared too great to ignore, and there were very real concerns among both developing countries and LDCs that without involvement in TRIPS, they would miss out on technology transfer and the capacity to attract foreign direct investment in the future. Most importantly, however, TRIPS contained many provisions that recognize the particular concerns and needs of developing countries and LDCs, ${ }^{8}$ and the transition periods meant that there was no immediate need to implement the Agreement (and correspondingly, that they bore no immediate economic costs as a result of the Agreement). ${ }^{9}$

The TRIPS Agreement is unprecedented insofar as it was the first WTO covered agreement to venture 'beyond the border' and thus to have a considerable impact upon on the internal legal

several developing countries, most notably Brazil, Argentina, India, China, and Taiwan, and extracted concessions from the respondents in a number of cases. In so doing, the US effectively promoted the linkage of IP and international trade. In 1988, the US went further and created Special 301 to examine and identify the "adequacy and effectiveness of intellectual property rights" in other countries. If problems are found to exist, countries are monitored and can be categorized as a "Priority Foreign Country" or included in the "Watch List" or "Priority Watch List”. See Sykes, Alan O. (1992), 'Constructive Unilateral Threats in International Commercial Relations: The Limited Case for Section 301', 23 Law \& Policy in International Business 2-3 (1992), pp. 263-330 at pp. 318-19; containing a table of cases decided under section 301. Likewise, and partly in response to the US provision, the European Union adopted Council Regulation 2641/84 to counter 'illicit' trade practices against European exporters. See Leirer, Wolfgang W. (1994-95), 'Retaliatory Action in United States and European Union Trade Law: A Comparison of Section 301 of the Trade Act of 1974 and Council Regulation 2641/84', 20 North Carolina Journal of International Law \& Commercial Regulation (1994-95), pp. 41-96. The EC repealed the Regulation upon the creation of the WTO. See Council Regulation 3286/94, available at <http://eur-lex.europa.eu/LexUriServ/LexUriServ.do?uri=CONSLEG:1994 R3286:20080305:EN: PDF $>$. The US did not, and Section 301 was subject to WTO dispute settlement. See also Report of the Panel, United States - Section 301-310 of the Trade Act of 1974, WT/DS152/R (22 December 1999).

${ }^{6}$ After initially listing China, India and Thailand on the Special 301 watch-list in 1991, the US first implemented sanctions and withdrew generalized system of preferences (GSP) concessions on Indian pharmaceutical products a year later. See Blakeney, Michael (1996), 'Trade-Related Aspects of Intellectual Property Rights: A Concise Guide to the TRIPs Agreement', Sweet Maxwell, p. 6. Developing country opposition to the inclusion of IPRs into the GATT weakened as the US continued to threaten and implement Section 301 and Special 301 sanctions. This was especially true of larger developing countries, notably Brazil and Korea. Perhaps more importantly, continued use of the unilateral retaliatory measures prevented the formation of effective coalitions against IPRs as a negotiating topic. Matthews, Duncan (2002), 'Globalising Intellectual Property Rights: The TRIPs Agreement' (Routledge, p. 33. The 'stick’ of Special 301 thus succeeded in convincing developing countries to adopt higher levels of domestic IP protection in exchange for continued preferential access to the US market. See ibid.

7 Developing countries initially argued that WIPO was the appropriate forum and then that the agreement should be limited to measures aimed at eliminating trade in counterfeit goods. The US, EC, Japan and Switzerland, however, successfully proposed a more ambitious agreement regulating a broad range of IPrelated interests. For a succinct history of the origins of the TRIPS Agreement and its negotiating process, see Matthews, Duncan (2002), 'Globalising Intellectual Property Rights: The TRIPs Agreement', Routledge, Chapter 1 (origins) and 2 (negotiations). For more detailed background on the TRIPS Agreement, see. Sell, Susan K. (1998) 'Power and Ideas: North-South Politics of Intellectual Property and Antitrust', State University of New York Press.

${ }^{8}$ See Mercurio, Bryan Christopher (forthcoming), 'TRIPS and Access to Essential Medicines', in: Prévost, Denise and Geert Van Calster (eds), 'Research Handbook on Environment, Health and the WTO', Edward Elgar, forthcoming 2013.

${ }^{9}$ TRIPS is the only covered agreement containing such transitional implementation periods. 
system of a Member. Examples of such impact can be seen through the minimum standards set out in TRIPS, the requirement to establish certain authorities, border controls measures and domestic enforcement mechanisms, including judicial review and even criminal liability for certain IPR offences. Unsurprisingly, the implementation costs of TRIPS for most developing countries have been considerable, in terms of both monetary and intellectual resources. This is true even of countries which had a fairly advanced IPR framework prior to the implementation of TRIPS, but even more so for developing countries that had not fully established a domestic IPR framework prior to TRIPS. It is therefore no exaggeration to state that for most, if not all, LDC Members of the WTO, effective implementation and operation of TRIPS was not possible in the decade following its creation.

Recognizing this reality, TRIPS allows for transitional arrangements for both developing countries and LDCs. The special and differential treatment towards LDCs begins in the Preamble itself, which not only recognizes that transitional arrangements are necessary when aiming 'at the fullest participation in the results of the negotiations' but also specifically highlights that due to the special developmental objectives and particular needs of LDCs 'maximum flexibility' should be accorded in the implementation of IP laws and regulation in order for them to create a sound and viable technological base. More specific provisions relating to transitional arrangements and LDCs are covered in Articles 65 and 66 of TRIPS.

\section{Transitional arrangements contained in Article 65 of TRIPS}

Part VI (Articles 65-67) of TRIPS provides for the transitional arrangements. Articles 65 and 66 define the length of time Members are given to bring their intellectual property laws and regulations into full conformity with the obligations of the Agreement. Article 65.1 stipulates a general transition period that applies to all WTO Members, regardless of their development status. According to this provision, Members were obliged to fully apply TRIPS one year after the date of entry into force of the WTO Agreement (i.e. 1 January 1995), meaning Members had until 1 January 1996 to bring their laws and regulations into compliance with TRIPS. Articles 65.2 and 65.3 provide developing country Members and Members with transitional economies an additional four years to comply with TRIPS, that is until 1 January 2000. One caveat to this transitional arrangement was that no extension was granted with regard to the compliance with the principles of national treatment and the most-favoured nation as contained in Articles 3, 4 and 5 of TRIPS. ${ }^{10}$

Moreover, according to Article 65.4, developing country Members which, prior to the enactment of TRIPS, had not extended product patent protection to areas of technology that had not been previously protected could further delay the implementation of such protection for a period of five years - that is, until 1 January 2005. Most notably, this extended transitional period applied to the pharmaceutical and agricultural chemicals sectors, which most developing countries did not previously protect. As countries manufacturing large amounts of generics (such as Brazil and India) did not previously provide product patents on pharmaceuticals, this extended period meant that manufacturers of generics in those countries could continue copying and producing drugs which would otherwise have required patent protection by the year 2000. The only caveat to this extended transitional period was that from 1995, countries were obliged to accept patent applications and keep them dormant in a patent

\footnotetext{
${ }^{10}$ See Article 65.2 TRIPS.
} 
'mailbox' until 2005, when the mailbox was unlocked and the applications assessed. ${ }^{11}$ Finally, Article 65.5 provides that any changes in the laws, regulations, and practice of a Member availing itself of these transitional arrangements shall advance the implementation of the Agreement, and must not result in a lesser degree of consistency with its provisions (the so-called 'no roll-back' provision).

\section{Transition periods for LDCs contained in Article 66.1 of TRIPS}

In view of the special needs and requirements of LDC Members, 'their economic, financial and administrative constraints, and their need for flexibility to create a viable technological base', Article 66.1 extended the transition period for LDCs to apply the TRIPS obligations to ten years, that is until 1 January 2006 (again, with the exception of Articles 3, 4 and 5). Moreover, the last sentence of Article 66.1 provides that the 'Council for TRIPS shall, upon duly motivated request by a least-developed country Member, accord extensions of this period'. Unlike the preceding transition periods set out in Article 65, Article 66.1 does not merely focus on providing LDCs with additional time to implement the Agreement. Instead, the provision recognizes that a rapid implementation of the Agreement could create a conflict with the economic interests and development priorities of LDCs. Therefore, this extension, as well as any subsequent extension, should allow LDCs to put domestic policies in place in order to ensure that the subsequent implementation of TRIPS will support and not hinder their socio-economic development.

Furthermore, and again unlike Article 65.5, Article 66.1 does not contain a 'roll-back' provision. In that respect, Article 66.1 could be seen as a further provision of special and differential treatment in the context of TRIPS. Such special and differential treatment is in line with Article 7 of TRIPS, which stipulates that IPR protection and enforcement should

contribute to the promotion of technological innovation and to the transfer and dissemination of technology, to the mutual advantage of producers and users of technological knowledge and in a manner conducive to social and economic welfare.

Such provisions are also in line with Article 66.2, which attempts to address the incapacity of LDCs to attract sufficient technology transfer from industrialized countries. Article 66.2 obliges developed country Members to

provide incentives to enterprises and institutions in their territories for the purpose of promoting and encouraging technology transfer to least-developed country Members in order to enable them to create a sound and viable technological base.

The language of Article 66.2, however, is vague and there is disagreement about the nature and quantity of the incentives that should be provided to the private sector to encourage such transfers. According to a study conducted by Surie Moon, it is unclear whether Article 66.2 has led to any increase in incentives for technology transfer to LDCs. ${ }^{12}$

\footnotetext{
${ }^{11}$ Several thousand applications which accumulated in India's 'mailbox' have yet to be assessed and are likely to be rejected. See supra note 8 , Section 2(b).

${ }^{12}$ For a more detailed analysis, see Moon, Suerie (2008), Does Article 66.2 Encourage Technology Transfer to LDCs? An Analysis of Country Submissions to the TRIPS Council (1999-2007), UNCTAD/ICTSD Project on IPRs and, Policy Brief Number 2 (2008).
} 


\section{Technical and financial assistance (Article 67 TRIPS)}

Given the potentially far-reaching legal and economic impact of TRIPS as well as the limited economic, financial and administrative capacity of developing country and LDC WTO Members, it became clear during the Uruguay Round that these countries would require considerable technical and financial assistance from developed country Members. Therefore, Article 67 requires developed country WTO Members to provide 'technical and financial assistance' in favour of developing country and LDC Members 'in order to facilitate the implementation' of the Agreement. This shall include, but is not limited to

assistance in the preparation of laws and regulations on the protection and enforcement of intellectual property rights as well as on the prevention of their abuse, and support regarding the establishment or reinforcement of domestic offices and agencies relevant to these matters, including the training of personnel.

The language used in Article 67 is vague, and the exact contours of the obligations it contains are unclear. Official WTO documents provide little guidance as to the exact meaning or interpretation of the terms in Article 67, and to date no dispute over the transitional arrangements in Part VI of TRIPS has been brought before the WTO's dispute settlement body. What is clear is that the provision does not impose any mandatory rules or particular methods of cooperation on developed country Members. That being said, the obligation on developed country Members to cooperate is triggered upon the receipt of a formal request from a developing country or LDC Member, followed by the conclusion of mutually agreed terms and conditions governing the cooperation activities.

Although Article 67 refers to technical and financial assistance, it seems clear that the assistance could include technical and financial assistance or only one of the two (although it also seems that the 'or' option is not the preferred course of action). The donor and beneficiary countries are free to determine the course of the negotiation process as well as the nature and scope of the cooperation. Developing country or LDC Members are at liberty to choose the developed country Member from which they request cooperation, but it remains unclear whether and how developed country Members could prioritize their efforts aimed at particular beneficiaries under this provision.

The vagueness and ambiguity of Article 67 has hampered its effectiveness. To put it mildly, Article 67 did not fulfil the expectations of many LDC Members during first ten years of TRIPS and instead has led to some frustration in the development community.

\section{The extension of the $L D C$ transition period for $L D C s$}

In response to rising awareness of the issues surrounding access to essential medicines, ${ }^{13}$ and in accordance with the last sentence of Article 66.1, ${ }^{14}$ Members agreed in the 2001 Doha Declaration on the TRIPs Agreement and Public Health to extend the transitional arrangements for LDCs until 2016 with respect to patents on pharmaceutical products and

\footnotetext{
${ }^{13}$ For an overview on access to essential medicines, see supra note 8.

${ }^{14}$ The last sentence of TRIPS Article 66.1 reads: 'The Council for TRIPS shall, upon duly motivated request by a least-developed country Member, accord extensions of this period.'
} 
exclusive marketing rights. ${ }^{15}$ Therefore, LDCs are under no obligation to provide for, nor to enforce patents and data protection with respect to pharmaceutical products until $2016 .{ }^{16}$

Prior to the expiration of the general transition period on 1 January 2006, Members agreed at the Hong Kong Ministerial Conference in late 2005 to provide LDCs with a last-minute reprieve and extend the transition period under Article 66.1 for the implementation of TRIPS for another seven and a half years to 1 July 2013. ${ }^{17}$ This provided LDCs with additional 'breathing space' but did not fully satisfy their desires. On the contrary, most LDCs supported a proposal submitted by Zambia in October 2005 requesting the TRIPS Council to extend the transition period for additional 15 years. ${ }^{18}$ In its request, Zambia (on behalf of the LDCs) argued that LDCs 'continue to face serious economic, financial and administrative constraints in their efforts to bring their domestic legal system into conformity with the provisions of the TRIPS Agreement' and that there is still a 'need for flexibility to create a viable technological base'. ${ }^{19}$ The proposal further argued that LDCs would need more time to take full advantage of the cooperation with developed country Members envisaged in Articles 66.2 and 67 TRIPS.

Although some developed WTO Members would have preferred to grant extensions to individual LDC Members on a case-by-case basis while others called for a five-year extension period, the looming expiration of the transition periods, coupled with the Ministerial Conference that was to be held in Hong Kong in late November 2005, put pressure on Members to resolve the issue collectively for all LDCs within a short time. The length of the extension - seven and a half years - seems merely to be the result of a bargaining process in which the LDCs originally requested 15 years and developed country Members a five-year period, rather than being the outcome of any holistic reasoning. ${ }^{20}$

In addition to the seven-and-a-half-year extension, the Decision also called for the establishment of a process which could facilitate the efforts and the cooperation of both LDC and developed country Members to integrate LDCs into the global IPR system. Therefore, the Decision contained four procedural elements:

- firstly, all LDCs were asked to provide the TRIPS Council, preferably by 1 January 2008, with as much information as possible on their individual priority needs for technical and financial cooperation in order to implement TRIPS;

\footnotetext{
${ }^{15}$ WTO Ministerial Conference, Declaration on the TRIPS Agreement and Public Health, WT/MIN(01)/DEC/2 (Nov. 20, 2001), para 7. The Declaration likewise granted LDCs an extension until 2013 to implement the TRIPs, more generally. This extension remains in force and has now been extended at least until the next Ministerial Conference.

${ }^{16}$ See World Trade Organization, Extension of the transition period under Article 66.1 of the TRIPS Agreement for least-developed country Members for certain obligations with respect to pharmaceutical products, Decision of the Council for TRIPS of 27 June 2002, 1 July 2002 (IP/C/25).

${ }^{17}$ See supra note 1.

${ }^{18}$ World Trade Organization, Request for an extension of the transitional period under Article 66.1 of the TRIPS Agreement, Communication from the Delegation of Zambia on behalf of the Least-Developed Country Members, 21 October 2005 (IP/C/W/457).

${ }^{19}$ See supra note 18 , paras. 4 and 5.

20 See World Trade Organization, Minutes of TRIPS Council Meeting held on 25-26 and 28 October, 29 November and 6 December 2005, 31 January 2006 (IP/C/M/49), paras. 243-285.
} 
- secondly, the provision calls on developed countries to provide technical and financial assistance to LDCs in accordance with Article 67 TRIPS so as to address the identified priority needs effectively;

- thirdly, the Decision mandates the WTO Secretariat to increase its cooperation with WIPO and other relevant international organizations to assist LDCs in the abovementioned needs assessment process and to make technical assistance and capacity building as effective and operational as possible;

- fourthly, the Decision introduced a 'no roll-back' provision that required LDCs to ensure that changes to their laws, regulations and practice made during the extended transitional period do not result in a lesser degree of consistency with TRIPS. ${ }^{21}$

The inclusion of a no roll-back provision for LDCs has been criticized by some LDCs and NGOs, which argue that it reduces the policy space available to LDCs during the transition period. ${ }^{22}$ Interestingly, the TRIPS Council Decision did not make any reference to or establish any links to the technology transfer provision in Article 66.2 TRIPS.

\section{State of play approaching the end of the first extension of the transition period for LDCs}

\section{Achievements and shortcomings of the priority needs assessment process}

As mentioned above, the TRIPS Council Decision of 29 November 2005 not only extended the original Article 66.1 transition period for LDCs by another seven and a half years to 1 July 2013, but also established a process in which LDCs were requested to provide information on what they consider as priorities for technical and financial assistance that would enable them to successfully implement the TRIPS Agreement.

Although all LDC Members were originally requested to provide the TRIPS Council with their priority needs assessments for technical and financial assistance by 1 January 2008, only six of the 32 LDC Members have thus far participated in the process. More specifically, the first LDCs to participate in the process were Uganda and Sierra Leone, which tabled formal submissions of their individual priority needs at the October 2007 meeting of the TRIPS Council. ${ }^{23}$ At the request of the TRIPS Council, Uganda then followed up its original priority needs assessment with a document entitled the Uganda Trade \& Intellectual Property Programme (UTIP) in June 2008. Sierra Leone quickly followed suit and presented its own national IP capacity building programme at the October 2008 meeting of the TRIPS Council. ${ }^{24}$ Bangladesh submitted its priority needs assessment in March 2010, Rwanda and Tanzania in October 2010, and Senegal in June 2011. ${ }^{25}$ The developed country Members of

\footnotetext{
${ }^{21}$ Similar to the 'no roll-back' provision in Article 65.5 TRIPS.

22 See supra note 20, Statement by Rwanda, para. 280.

${ }^{23}$ World Trade Organization, Council for TRIPS, Priority Needs for Technical and Financial Cooperation: Communications from Uganda, 9 October 2007 (IP/C/W/500) and 27 May 2008 (IP/C/W/510); Communications from Sierra Leone, 3 October 2007 (IP/C/W/499) and 22 October 2008 (IP/C/W/523).

${ }^{24}$ See second submissions of Uganda and Sierra Leone in supra note 23.

${ }^{25}$ World Trade Organization, Council for TRIPS, Priority Needs for Technical and Financial Cooperation: Communication from Bangladesh, 23 March 2010 (IP/C/W/546); Communications from Rwanda, 7 June 2010
} 
the WTO, as well as the WTO Secretariat, commended these LDCs on their submissions and invited others to follow suit. Unfortunately, the other 26 LDC Members of the WTO have not formally submitted their priority needs assessment almost five years after the original deadline.

Some NGOs and other commentators criticized the priority needs assessment as merely a delay tactic used by developed country Members to further postpone honouring their promises for assistance. These critics also claimed that the priority needs assessment would force LDCs to spend already scarce resources on collecting data and information regarding the status of their implementation of TRIPS. ${ }^{26}$ Most WTO Members, however, considered the priority needs assessment process as an invaluable exercise that fulfils a number of purposes. For instance, the priority needs assessment allows LDCs to table concrete and specific demands which could create the political momentum needed to mobilize potential donors as well all national stakeholders in the beneficiary country. Correspondingly, the priority needs assessment also provides potential donors with the necessary information to clearly identify what support the individual LDC actually requests and to tailor its donor programmes better to meet the needs of the requesting country. Moreover, for many LDCs, such a stocktaking exercise provides a unique opportunity to create awareness and consensus among a variety of internal institutions and stakeholders, which is a necessary precursor to developing and implementing a national innovation and IP policy. Likewise, a successfully completed priority needs assessment is a strong signalling device as it demonstrates a national commitment towards IP reform, which could be seen by some as being essential for LDCs to attract technical and financial assistance. Moreover, the priority needs assessments provide potential donors with an insight into the socio-economic context and the institutional dynamics of TRIPS implementation in the potential beneficiary country, again allowing for more targeted and tailored technical and financial assistance.

Unfortunately, the TRIPS Council Decision of 2005 did not specify any formal requirements or a particular mechanism for the conduct and submission of priority needs assessments by LDCs. Therefore, the appropriate scope, depth, breadth and quality of the priority needs assessments remain unclear. Likewise, it is not further specified who should be funding and conducting these exercises. As a result, the priority needs assessments submitted thus far differ significantly in quality, scope, analytical reasoning and structure. In the case of Uganda and Sierra Leone, the priority needs assessment process was mainly funded by the United Kingdom Department for International Development (DFID) and both governments received considerable support and assistance from the International Centre for Trade and Sustainable Development (ICTSD) and a specialized consulting firm. On the other hand, Bangladesh conducted its priority needs assessment on its own without any donor assistance or support. The submissions also differed substantively, and approached the issue of how to attract the attention of potential donors in a significantly different manner. For instance, Uganda complemented the needs assessment with a fully-developed national capacity building programme referred to as the Uganda Trade and Intellectual Property (UTIP), a programme

(IP/C/W/548) and 21 October 2010 (IP/C/W/548/Add.1); Communication from Tanzania, 21 October 2010 (IP/C/W/552); Communication from Senegal, 27 June 2011 (IP/C/W/555).

${ }^{26}$ See for instance The South Centre/Center for International Environmental Law (2006), 'Extension of the transition period for LDCs: flexibility to create a viable technological base or simply (a little) more time?’ IP Quarterly Update, First Quarter 2006, p. 6. 
that contained detailed descriptions of activities and a clear implementation timetable with a budget of a US\$ 2 million. In contrast, Bangladesh submitted only a brief priority needs assessment paper of 20 pages that included a one-page rough budget requesting approximately US\$ 71 million. ${ }^{27}$

Overall, the priority needs assessments submitted were well-considered, carefully conducted exercises which thoughtfully analysed the perceived needs of the LDC concerned. From a development aid perspective though, many of the proposed implementation plans did not meet the standards and principles of aid effectiveness that have been developed over recent decades (e.g. in the Paris Declaration). ${ }^{28}$ Moreover, the priority needs identified are often not compatible with the actual capacities or project management requirements of the targeted donors. Thus, it is unrealistic for the LDC concerned, or for interested NGOs, to expect that the requests stemming from the priority needs assessment will be immediately met. Instead, the formulation of requests via the priority needs assessment should be viewed as only the first step in what development cooperation experts call project-cycle management (PCM), not as something that will automatically trigger to the implementation of the requested projects.

There also appears to be confusion, or at the very least a certain disconnect, between LDCs and potential donors, on the purpose of the technical and financial assistance requests contained in the priority needs assessment. For instance, while some of the requests contained in the priority needs assessments go beyond achieving compliance with TRIPS obligations and are designed to contribute to the establishment of a national IP system that is beneficial to the country's socio-economic development (e.g. Bangladesh's priority needs assessment requests US\$ 14.5 million for community-based museums and for conducting research on traditional knowledge), ${ }^{29}$ some potential donor countries believe that technical and financial assistance should be exclusively targeted at bringing LDCs' intellectual property laws and institutions into compliance with the obligations under TRIPS.

As a consequence of these asymmetries, it remains unclear what the follow-up procedure should be once an assessment has been submitted to the TRIPS Council. The six LDCs that have so far participated in the exercise have received little response from developed country Members and insufficient funding to make substantial progress on the implementation of their national IP plans. Above all, the submission of a priority needs assessment did not trigger any substantive additional technical and financial assistance. Overall, it is fair to conclude that the

${ }^{27}$ See Council for TRIPS, Priority Needs for Technical and Financial Co-operation, Communication from Bangladesh, 23 March 2010 (IP/C/W/546), para. 39.

${ }^{28}$ The Paris Declaration on Aid Effectiveness had been endorsed in 2005 by more than 100 signatories (from donor and recipient country governments, multilateral donor agencies, regional development banks and international agencies) in order to address the fact that development aid had become increasingly fragmented, less predictable, less transparent and more volatile. The Declaration represented a broad consensus among the international community on how to make development cooperation more effective by introducing new mechanisms such as conditionality, capacity building and support for governance. Furthermore, it focused on five principles: ownership, alignment, harmonization, managing for results, and mutual accountability. For an overview on aid effectiveness, see Killen, Brenda and Andrew Rogerson (2010), 'Global Governance for International Development: Who’s in Charge?’, Development Brief, Issue 2/2010 or Kharas, Homi (2011), 'The Evolving International Architecture for Development Cooperation', Policy Paper 2011/11, The Brookings Institution.

${ }^{29}$ See supra note 27 , para. 39. 
priority needs assessment process has not met the legitimate expectations of LDCs. ${ }^{30}$

\section{Impact on the provision of technical and financial assistance by developed country Members}

To some, the obligation to provide technical and financial assistance has mainly been a tool used by industrialized countries to convince developing countries and LDC Members to accept and agree to TRIPS. ${ }^{31}$ While such statements and sentiment are debatable, what is clear is that neither the industrialized world nor LDCs have prioritized LDC implementation of TRIPS over fifteen years since the creation of TRIPS. Instead, developed country Members focused their efforts on encouraging full implementation of TRIPS in emerging market economies such as Brazil and India where powerful economic interests are at stake.

This being so, the TRIPS Council Decision of 2005 put the developed country Members in a somewhat inconvenient position. The newly-established priority needs assessment process linked the LDC obligation to implement TRIPS at least indirectly with the provision of technical and financial assistance under Article 67 TRIPS. Consequently, the Decision has limited the discretion of the donor countries as to how, where or to what extent they engage in technical and financial assistance in the field of IPRs (IPRTA). At the same time, these submissions raised considerable expectations in the developing world and the continued failure to successfully address the LDCs' priority needs could lead to growing resistance to further progress in the international protection of IPRs.

On the declaratory level, developed country Members assert that they are fully aware of the importance of technical and financial assistance in order to support LDC Members in taking the steps necessary to enable them to comply with their obligations under the TRIPS Agreement. In that respect, they have commended the LDCs that have submitted priority needs assessments and invited others to follow suit.

So far, however, most industrialized countries have either not provided any such IPRTA or have concentrated their efforts mainly on middle-income countries with which they have close political or economic ties. In addition, while some national IP institutions in developed countries have certain office-to-office cooperation activities with a few partner countries, these activities focus mostly on beneficiary countries where they are already engaged in economic, trade and development cooperation. It is also clear that the classic motive for IPRTA activities includes the assumption that such IPRTA should lead to improved protection for national IP rights holders abroad. As a consequence, most IPRTA has been provided to new emerging market economies where protection for IPR holders from developed countries is a key economic interest. Selecting emerging market economies as partner countries also makes sense as they are normally at a stage of development where they could reap significant benefits from having a functional IP system in place.

Some developed country Members have not made any provision for specialized IPRTA programmes in their development aid budgets (e.g. Canada), while others have either only

\footnotetext{
${ }^{30}$ Some of the participants expressed their disappointment about the exercise. See for example World Trade Organization, Council for TRIPS, Minutes of Meeting on 8-9 June 2009, 28 September 2009 (IP/C/M/60), Statement by Uganda, paras. 71-72.

${ }^{31}$ See World Trade Organization, Council for TRIPS, Minutes of Meeting on 21 September 1995, 20 October 1995 (IP/C/M/3), para. 54.
} 
IPRTA programmes with a strictly regional focus (e.g. Australia in the pacific region) or they mainly conduct such activities primarily through WIPO (e.g. Japan). As a consequence, the various developed country Members have approached this issue differently; some are planning to provide technical assistance on a bilateral case-by-case basis within their existing development programmes (by reshuffling their trade cooperation budgets), while others have yet to decide how best to meet their obligation under Article 67 of TRIPS.

Most developed country Members seem to recognize the need for a certain level of coordination of their efforts to provide technical and financial cooperation under Article 67, with many delegations expressing their concern that without adequate coordination technical assistance projects could carry both the risk of duplication of efforts that are already underway and that of having no sustainable impact. ${ }^{32}$ More worrying, however, is that some delegations have indicated that their development aid budgets do not contain any specific budget lines earmarked for IP-related projects. Moreover, budgets for development cooperation in the field of trade are generally limited, with a substantial amount of assistance programmes being tied to particular regions or trading partners.

Another difficulty facing several developed country Members has been in attracting the interest of national development cooperation agencies in redirecting development aid to IPRs. This difficulty probably arises because the socio-economic impact of TRIPS is still not obvious and the benefits of IP reforms will be indirect and long-term.

In summary, it is fair to say that seven years after the TRIPS Council Decision of 2005, most developed country Members have still not managed to come up with a comprehensive (internal or external) strategy on how to position themselves with regard to the priority needs assessment process and to what extent and under what conditions they are actually intending to provide comprehensive IPRTA.

\section{Efforts of the WTO Secretariat}

The TRIPS Council Decision of 2005 requested the WTO Secretariat to enhance its cooperation with relevant international organizations in order to assist LDC Members. In that context, the Decision made particular reference to the provisions on technical assistance and cooperation mentioned in the cooperation agreement that WIPO and the WTO concluded in1995. ${ }^{33}$ The two organizations also launched a Joint Initiative on Technical Cooperation for Least Developed Countries in June 2001. ${ }^{34}$

\footnotetext{
${ }^{32}$ See for example World Trade Organization, Council for TRIPS, Minutes of Meeting on 8-9 June 2009,28 September 2009 (IP/C/M/60), Statement by Switzerland, paras. 74-78.

33 See World Trade Organization, Council for TRIPS, Agreement Between the World Intellectual Property Organization and the World Trade Organization, 13 December 1995 (IP/C/6). In Article 4 of the said Agreement, WIPO and the WTO committed themselves to enhance their technical assistance relating to the TRIPS Agreement and to make it available also to those developing countries that are Members of the partner organization. This is particularly relevant for LDC WIPO Members such as Laos that are currently in the process of acceding to the WTO, as it puts them in a position to profit from IPRTA under Art. 67 TRIPS. Furthermore, the two organizations agreed to keep in regular contact and to exchange information on this matter.

${ }^{34}$ See World Trade Organization, WIPO and WTO Launch New Initiative to Help World's Poorest Countries Press Release, 14 June 2001 (Press/231).
} 
Since the TRIPS Council Decision of 2005, the WTO Secretariat has made considerable efforts to create awareness of the issue and to organize matchmaking with potential donor countries. For example, following the publication of the priority needs assessments of Uganda and Sierra Leone, the WTO Secretariat organized informal meetings with developed country Members to consider how the priority needs identified could best be met, thus facilitating initial bilateral contacts to look at potential contributions by developed country partners. In October 2009, the WTO Secretariat hosted a WTO Workshop on the priority needs assessment process at the request of the LDC group, which aimed to facilitate an exchange of views between all actors. Responding to another request by the LDC group, the WTO Secretariat organized three regional workshops on the priority needs for these countries in $2010 .^{35}$ Furthermore, key representatives from LDCs, developed countries and interested international organizations took part in a symposium on LDCs' needs assessment in Geneva in October 2011. This review session concluded that the existing technical assistance contact points between the partners should be used in a more systematic manner. More specifically, the participants in the review session recommended the establishment of small coordination groups in order to respond comprehensively to the priority needs assessments tabled. The participants also recommended increased coordination to support further priority needs assessments and to respond to the needs that have already been identified. Finally, the participants agreed on the need for practical tools and common resources which can provide methodological advice to LDCs on how to participate in the priority needs assessment process. $^{36}$

As a result of the review session, Switzerland requested that the WTO Secretariat contact the Secretariat of the Enhanced Integrated Framework (EIF) and the coordinator of the Aid-forTrade initiative (AfT) ${ }^{37}$ with a view to gathering and presenting information on how these existing multilateral mechanisms, including their expertise and funds, could be used to assist in the implementation of the priority needs requested under Article 67 of TRIPS. ${ }^{38}$ Finally, LDCs recently requested developed country Members to state more concretely how they intend to respond to the LDCs' priority needs assessment. ${ }^{39}$ In that respect, Nigeria, on behalf of the African Group, proposed in the TRIPS Council that the Secretariat prepare a note aimed at indicating areas that had been implemented as well as areas still needing attention in each of the LDC Members that have submitted their priority needs assessment. ${ }^{40}$

\footnotetext{
${ }^{35}$ See therefore supra note 32, Request from the LDC Group, paras. 67-68.

${ }^{36}$ See World Trade Organization Council for TRIPS, Minutes of Meeting on 24-25 October and 17 November 2011, 15 February 2012 (IP/C/M/67), paras. 330-335.

37 Both the Enhanced Integrated Framework (EIF) and the Aid-for-Trade initiative (AfT) will be further explained in section 5 of this chapter on page 19.

${ }^{38}$ See supra note 32, paras. 74-78.

${ }^{39}$ The EU and Japan have already provided such a report. See World Trade Organization, Council for TRIPS, Technical Cooperation Activities and Assistance for Least Developed Countries, Communication from the European Union, 20 February 2012 (IP/C/W/568) and Complementary Report on Technical Cooperation Activities for Least Developed Countries, Communication from Japan, 19 July 2012 (IP/C/W/572).

${ }^{40}$ See World Trade Organization Council for TRIPS, Minutes of Meeting on 24-25 October and 17 November 2011, 15 February 2012 (IP/C/M/67), para. 339.
} 
4. The need for enhanced coordination on various levels in order to make the priority needs assessment process work

To date, developed country Members' response to the priority needs assessments submitted has been somewhat disappointing. Except for informal talks among industrialized countries and a few matchmaking workshops and meetings with LDCs, no comprehensive and coordinated follow-up has taken place and only very limited IPRTA has been provided. There is a variety of reasons for this lack of coordination.

Foremost is that IPRTA is a relatively new topic in the field of development cooperation and the track record of IPRTA in LDCs is very limited. There is still a lack of research and best practices when it comes to the implementation and the impact assessment of TRIPS in LDCs. ${ }^{41}$ While the commitment and the ability to absorb IPRTA is usually relatively high in emerging markets, the conditions in LDCs are very different. LDCs have a limited absorption capacity as their legal and institutional framework for IP protection is usually in an embryonic stage and they lack educational and professional capacity in the field of IP. Additional obstacles normally associated with working in LDCs (e.g. remote rural areas, digital gap, and brain drain) also are known to affect the efficiency of such IPRTA projects. ${ }^{42}$

Another important reason for the slow progress in the priority needs assessment process and in the provision of IPRTA is the abundance of actors within the LDCs. On the one hand, various government agencies are involved in or affected by the implementation of TRIPS (the national IP offices, the ministries of industry, trade, finance, foreign affairs, justice, science and technology, culture, education, health, and agriculture, as well as enforcement agencies such as customs, police and courts). ${ }^{43}$ On the other hand, a myriad of non-governmental stakeholders also have to be included in the decision-making process in order to effectively strengthen the national IP system (IP professionals, industry, inventors, collecting societies, academics, chambers of commerce, teachers, and the media as well as the public). The inclusion of such large and diverse groups inevitably affects the speed and efficiency of IPRTA projects.

As hinted at earlier, there is also a great need for internal national coordination on the donor side. The starting point is the inclusion of national IP offices. Many developed country Members, however, still have separate national offices for industrial property and copyrights, and these national IP offices normally have neither experts nor spending power when it comes to technical assistance activities. Thus, even the inclusion of national IP offices has proven to

\footnotetext{
${ }^{41}$ There is a consensus among practitioners that IPRTA should be in alignment with best practices and general principles of development cooperation as stated for example in the Paris Declaration on aid effectiveness. In 2010, the WTO commissioned a consulting firm to draft a Guidebook for LDCs on how to implement TRIPS. This document has not yet been published. See Pengelly, Tom and Jakob Engel (forthcoming), 'Using technical and financial assistance for implementation of the TRIPS Agreement: A guidebook for LDCs'. For the best available source of information on IPRTA best practice, see Leesti, Mart and Tom Pengelly (2007), 'Assessing Technical Assistance Needs for Implementing the TRIPS Agreement in LDCs, ICTSD Programme on Intellectual Property Rights and Sustainable Development LDC - A Diagnostic Toolkit', International Centre for Trade and Sustainable Development (ICTSD), Geneva, Switzerland.

42 See Leesti, Mart (2006), Special Challenges for IP TA in Capacity Building in an LDC, available at http://www.iprsonline.org/ictsd/docs/LDCToolkit-final.pdf

${ }^{43}$ See ICTSD (2011), 'LDC Needs Assessment under TRIPS: The ICTSD Experience (2007-2011)’, Information Note No.19, International Centre for Trade and Sustainable Development, Geneva.
} 
be more difficult than might be assumed. Moreover, as the TRIPS Agreement is only one part of a wider framework of trade relations, the national trade ministries as well as the trade diplomats negotiating in Geneva must also be included in the process. As the budgets for development cooperation are normally managed and controlled by national development cooperation agencies, these agencies must also play a role in the process. Furthermore, since the foreign affairs ministry is usually in charge of the official relationship with a potential beneficiary country (and likely have some representation in that country) it too should be included in the process. Again, with so many agencies and interests represented it has proven difficult to effectively coordinate IPRTA projects.

Further complicating the matter is that IP is extremely controversial in the development cooperation community and most representatives of development agencies have only a limited understanding of the underlying legal and socio-economic mechanisms. Put bluntly, there is widespread distrust among many of the above-mentioned stakeholders concerning the fundamental issue of whether increased IP protection is actually beneficial for LDCs or whether it simply takes away 'policy space' in a manner detrimental to meeting the needs and desires of LDCs. In light of this tension, development agencies often do not view the modernization of IP laws and institutions as a priority, given the many other competing interests of LDCs, thus making them reluctant to fund these sorts of initiatives and programmes.

Another set of problems can be attributed to the vagueness of the TRIPS provisions and the design of the priority needs assessment process. As stated above, the exact nature and scope of the obligation contained in Article 67 of TRIPS remain unclear. Unanswered questions include whether the obligation merely requires a certain financial or technical input or whether it is an outcome-oriented obligation. In other words, it remains unclear whether a developed country Member is in compliance with its obligations under Article 67 when it provides a certain level of IPRTA or whether it is only in compliance when an LDC has finally managed to implement TRIPS. This ambiguity also creates a certain liability problem for developed country Members; thus, by agreeing to provide technical and financial assistance, it is also unclear whether the developed countries have moved away from a position of merely demanding implementation of TRIPS to a position where they have at least partly taken some responsibility for LDCs' implementation of TRIPS.

As mentioned above, the quality and the scope of the priority needs assessments are very heterogeneous. Moreover, the implementation plans attached to some of the priority needs assessments do not follow standardized development cooperation procedures and principles which normally provide for the inclusion of the donors' capacities and preferences in the project design. As a result, it is highly unlikely that potential donors would support these implementation plans in an integral and comprehensive manner. Instead, a donor country will first have to assess the feasibility of a project and conduct its own project design to fulfil the requirements of its national development cooperation agency in terms of measurable outcomes, monitoring, accountability, ownership, and sustainability.

From a procedural point of view, it is unclear what the follow-up process to LDCs' priority needs assessments should be. The present situation creates uncertainty for all LDCs as it is not clear that investing already scarce resources into conducting an IP priority needs assessment will eventually result in the receipt of substantial technical and financial assistance in the identified priority areas. Some developed countries believe Members should respond to 
LDCs' requests on a first-come, first-served basis, others favour a case-by-case approach and some believe that a transparent and predictable process should be developed within the existing coordinating structures. It is also unclear how technical and financial assistance provided to LDCs under Article 67 could be coordinated with other existing mechanisms and initiatives in this area in a manner that is useful and avoids unnecessary duplication.

This paper argues that increased coordination at various levels, including within the donor countries and the beneficiary LDCs, as well as within the international development community would resolve some of the above-mentioned dilemmas. On the one hand, greater coordination in the funding of technical assistance could range from opening new funds and creating joint initiatives to the attempts to tap into existing funding mechanisms (e.g. funding through the EIF). On the other hand, cooperation is also essential in the actual provision of technical assistance. This could range from mere information exchange between the developed country Members about which donor is implementing a particular activity (checklist approach) to outsourcing the implementation of entire projects to a central coordination body.

Again, the difficulty lies in actually creating a mechanism to increase coordination efforts. Many developed country Members emphasize the need to identify a central coordination body - e.g. to set up a sort of "clearing house" mechanism - while others would like WIPO and/or WTO to assume an essential role in this regard. Those favouring WTO involvement point to the WTO/WIPO Cooperation Agreement and the Joint Initiative as evidence of its interest in the subject matter. In contrast, several other developed country Members oppose WTO involvement for systemic reasons; they argue that the WTO should not assume the role of a development organization and that this type of activity could set a precedent for other trade sectors. As mentioned before, several developed country Members have identified the EIF as a possible channel of cooperation. In the following section we will further analyse this option.

\section{The Enhanced Integrated Framework (EIF) and Aid-for-Trade (AfT) as potential coordinating bodies}

In order for Members to agree on a coordinated, efficient and expeditious response to the priority needs identified by LDCs in their assessments, the role of existing multilateral mechanisms or frameworks that could come into play to address these needs merit further consideration.

In response to requests from a number of delegations, the WTO Secretariat compiled information on potential coordinating roles of the EIF and AfT in the needs assessment process for LDCs, with a particular focus on how the expertise and monetary resources of these two existing multilateral mechanisms could be made use of to assist LDCs in establishing their individual priority needs assessments and receiving IPRTA. ${ }^{44}$

The EIF is a multi-donor programme that strengthens cooperation among donors, six core partner agencies (International Monetary Fund (IMF), International Trade Centre (ITC), United Nations Conference on Trade and Development (UNCTAD), United Nations Development Programme (UNDP), World Bank and WTO)), observer agencies, and other

\footnotetext{
44 See WTO Secretariat Note on the Aid for Trade Initiative and the Enhanced Integrated Framework (IP/C/W/544). The note provides an overview on the funding mechanisms of both initiatives.
} 
development partners which are supporting the LDCs' trade agenda. Both beneficiaries and donors benefit from the EIF: LDCs can use the EIF as a vehicle to assist in coordinating donor support and to attract additional AfT resources, whereas donors can sign up to the EIF as a vehicle to deliver on their initial AfT commitments. The EIF process might be considered cumbersome, but is thought to be essential to ensuring proper use of funds and to maximize the effectiveness of the aid in LDCs. In order to receive funding from the EIF, LDCs must first undertake a so-called Diagnostic Trade Integration Study (DTIS) to identify a list of priority reforms in the field of trade. These reforms must be validated by national stakeholders and the national government. The EIF then supports the integration of these trade priorities into national development strategies and identifies sources of adequate funding for key priorities. Of course, using the EIF as a tool to fund IP-priorities identified in the priority needs assessment can only occur when an LDC identifies IP-related needs as a priority in its DTIS framework. In summary, using the EIF mechanism in the coordination of the priority needs assessment process would require LDCs to further align all national stakeholders towards improving the legal and institutional IP framework. When such alignment occurs, LDCs are provided greater access to substantial multilateral or bilateral funding opportunities.

\section{Towards a second extension of the transition period for $L D C s$}

With the upcoming expiration of the extended transition period for LDCs on 1 July 2013, discussions concerning LDCs' implementation of TRIPS have resumed in the TRIPS Council. Unfortunately, but perhaps not unexpectedly, the discussions did not start positively. Instead, the initial discussions quickly became a blame-game and finger-pointing exercise. Fortunately, the discussions have now progressed and many Members have begun to slowly realize that there is a need for a more constructive and comprehensive approach to what has now become a pressing issue.

At the November 2011 meeting of the TRIPS Council, Bangladesh submitted a proposal on behalf of the LDC Group requesting a further extension of the transition period. ${ }^{45}$ The proposal instructs the TRIPS Council

to take a favourable decision in this regard and report thereon to the WTO ninth Ministerial Conference to be held in December 2013. ${ }^{46}$

The proposal found support in the TRIPS Council, and the Members agreed to recommend the following text to the General Council to be forwarded to the Eighth Ministerial Conference, held in Geneva in December 2011, for consideration:

Ministers invite the TRIPS Council to give full consideration to a duly motivated request from Least Developed Country Members for an extension of their transition period under Article 66.1 of the TRIPS Agreement, and report thereon to the WTO Ninth Ministerial Conference. $^{47}$

In their Decision of 17 December 2011, the Ministers invited the TRIPS Council:

\footnotetext{
${ }^{45}$ See World Trade Organization, Elements Paper on the Extension of the Transition Period under Article 66.1 of the TRIPS Agreement, Communication by Bangladesh on behalf of the LDC Group, 11 November 2011 (IP/C/W/566).

${ }^{46}$ See supra note 45.

${ }^{47}$ See World Trade Organization, Annual Report (2011) of the Council for TRIPS, Addendum, 17 November 2011 (IP/C/59/Add.2).
} 
to give full consideration to a duly motivated request from Least-Developed Country Members for an extension of their transition period under Article 66.1 of the TRIPS Agreement, and report thereon to the WTO Ninth Ministerial Conference. ${ }^{48}$

Curiously, the length of the second extension period has not yet been agreed, but informal discussions with LDC delegations suggest the requested period is 15 years; thus, the transitional period would extend until the year 2028. The length of the extension will be controversial, and it is expected that several developed country Members will insist on a considerably shorter time. With this important decision likely to remain contentious for some time, it is likely that another extension of the transition period for LDCs will be granted in the final TRIPS Council Meeting taking place before the expiration of the current transition period on 31 June 2013. At this stage, neither LDCs nor developed country Members seem interested in discussing even more contentious alternatives to a simple extension of the transitional periods. This is unfortunate for a number of reasons, and Section IV not only introduces those reasons but also offers several potential alternatives.

\section{The drawbacks of an unconditional second extension of the transition period}

1. Why granting an unconditional second extension of the transition period might be detrimental to the implementation of TRIPS by LDCs?

As the deadline of 1 July 2013 is fast approaching, agreeing on another extension of the transition period for LDCs seems to be a pragmatic next step. This is particularly the case as the vast majority of LDCs have not made substantial progress in the implementation of TRIPS. Indeed, most of the LDC WTO Members have not yet addressed the issue domestically or considered it a priority within their national development policies. Thus, it seems premature to expect these countries to be ready to implement TRIPS by mid-2013. Conversely, developed country Members have to date mainly focused on shielding themselves from unspecified IPRTA requests and the submission of the first priority needs assessments has revealed the extent of their unpreparedness. Granting an unconditional extension of the transition period for all LDCs would therefore be a convenient way for both parties to buy time and to avoid any potential conflicts in the TRIPS Council.

But there are some significant potential downsides to simply extending the transition period. Foremost, the experience of the last decade strongly indicates that an extension alone would not lead to any IP-related improvements in LDCs. On the contrary, an unconditional extension would not resolve anything but would only further postpone the implementation of TRIPS by LDCs. At the same time, another unconditional extension would undermine the credibility of the TRIPS regime and inevitably lead some - including these authors - to question whether LDCs will ever have to comply with TRIPS. More generally, another unconditional extension would undermine the credibility of a multilateral system which is premised on the belief that the protection and enforcement of IPRs are beneficial for the

\footnotetext{
48 See World Trade Organization, Transition Period for Least-Developed Countries under Article 6.1 of the TRIPS Agreement, Decision of 17 December 2011, 19 December 2011 (WT/L/845).
} 
growth and development of Members, including LDCs. ${ }^{49}$

Instead, it is proposed that what is needed is to increase the efficiency, transparency and predictability of the priority needs assessment process so that it creates enough incentives for both LDCs and developed countries to engage more effectively in integrating LDCs into the international IP system. As mentioned earlier, the submission of a priority needs assessment seems to be the crucial first step for LDCs and without it, no progress towards improved TRIPS implementation can be expected.

The TRIPS Council Decision of 2005 already links the rights and obligations contained in Articles 66.1 and 67 of TRIPS. In the current setting, however, each of these two provisions blocks the realization of the other: LDCs argue they could have implemented TRIPS had they received substantial IPRTA while developed country Members claim that they would be willing to provide IPRTA if LDCs would consider TRIPS implementation as an important development priority and participate more actively in the priority needs assessment process. A synergy between these two provisions can only be achieved if all Members manage to agree on an efficient, transparent and predictable process which ensures not only that LDCs will actively participate in the process but also that they will receive substantive support for embarking on a path of IP reform. Conversely, developed country Members require assurances of LDCs' commitment to the process and that IPRTA will be spent effectively.

\section{Assessing the consequences if no extension or only a very short extension of the transition period were to be granted}

Given the above, this article argues that an unconditional extension of the transition period for LDCs to implement TRIPS would not only lead to a further postponement of LDCs' integration into the international IP system without resolving any of the underlying issues, but would also lead to a stagnation (if not to a reduction) in the fulfilment of developed country obligations to provide IPRTA.

Before providing alternative remedies to the current dilemma, however, we first assess the consequences of the TRIPS Council not approving a second extension of the transition period. If no further extension is granted, it is clear to all that from 1 July 2013 most LDCs would not be in compliance with the TRIPS. Without denigrating such important obligations, practically speaking it seems very unlikely that another WTO Member (whether it be an industrialized country Member, developing country or LDC) would bring an IP-related WTO claim against an LDC; put simply, LDC markets are too insignificant to warrant such a claim and such an attempt would most likely be a public relations disaster for the complainant country and the affected industries. On the other hand, if the TRIPS Council only grants another extension for a minimal period the situation becomes even less stable. Not only is there the issue of the continuing negotiations and uncertainty, but the threat of a 'deadline' and eventual noncompliance remains relevant.

Section V outlines several potential alternatives to an unconditional extension of the transition

\footnotetext{
49 Indeed, similar concerns were raised in 2005 at the time of the first extension of the transition period. See for example Kennedy, Kevin (2006), 'The 2005 TRIPS Extension for the Least-Developed Countries: A Failure of the Single Undertaking Approach?’, 40 International Lawyer (2006), pp. 683-700.
} 
period. While admittedly none of the remedies presented provide the proverbial silver bullet, we argue that they all offer a better solution than that of a mere, unconditional extension of the transition period. Furthermore, the proposed alternatives are not mutually exclusive, and some of these remedies could be combined to increase the impact and more precisely tailor any potential resolution.

\section{Potential alternatives to an unconditional second extension of the transition period}

In this section we propose four potential alternatives to an unconditional second extension of the transition period. We briefly analyse the feasibility of each of the proposed alternatives from a legal, systemic and political point of view. In particular, we look to other fields of international law or international negotiations that may provide alternative legal mechanisms or incentive structures useful for the implementation of TRIPS by LDCs. The four alternative proposals are as follows:

- granting a moratorium on claims being brought against LDCs under TRIPS;

- introducing conditions for a second extension of the transition period;

- applying a more gradual and development-oriented concept of TRIPS implementation for LDCs; and

- identifying additional incentives for LDCs and developed countries to cooperate more actively towards LDCs' integration in the global IP system.

\section{Granting a moratorium on claims being brought against LDCs under TRIPS}

As bringing a claim against a non-compliant LDC is neither desirable nor feasible, an alternative approach could be for WTO Members to agree on a dispute settlement moratorium whereby Members commit themselves not to institute proceedings against LDCs for a set period. This approach has a number of advantages over another extension of the transitional period. First, a moratorium is a more intellectually honest way of dealing with the inability of LDCs to comply with TRIPS. Formally admitting that the LDCs are not in compliance with TRIPS is not only truer to the 'single undertaking' model of WTO governance that Members appear to cherish but also more realistic than simply providing multiple extensions in the false hope that implementation will at some point miraculously occur. For this reason, a moratorium may be a more credible approach. Moreover, a moratorium could also be more effective than another extension of the transitional period as it would not exempt LDCs from compliance nor technically excuse the non-compliance. It would simply recognize the inability of LDCs to comply with TRIPS and therefore grant them special and differential treatment. Furthermore, it would put constant pressure on all WTO Members to take action and would offer incentives for those LDCs that have so far undertaken the priority needs assessment and are making progress in the implementation of TRIPS.

However, the introduction of such a moratorium alone would neither resolve most of the above-mentioned dilemmas with regard to unlocking IPRTA nor would it actually improve LDCs de-facto TRIPS compliance. 


\section{Introducing conditions for a second extension of the transition period}

Most Members of the TRIPS Council seem to agree that the priority needs assessment process is an essential stocktaking exercise for all LDCs, not only in order to attract IPRTA but also simply as a developmental and governance exercise. Undertaking this process not only identifies the major shortcomings of an LDC's legal and institutional framework for the protection of IP, but it also has the potential to create political momentum for the LDC to actively engage in the multilateral system and improve its IP systems. Therefore, undertaking a priority needs assessment is viewed as having an essential role to play in encouraging LDCs to implement TRIPS. It must be remembered, however, that the TRIPS Council Decision of 2005 introduced the quasi-requirement for LDCs to submit their priority needs assessments 'preferably by 1 January 2008' and the requirement was virtually ignored. ${ }^{50}$ In other words, failing to enforce deadlines does not lead to enhanced compliance. We therefore propose that if a second extension is granted, a more binding timeframe - for instance stating a deadline for compliance 'by no later than' instead of the more hortatory language of 'preferably by' should be introduced. Importantly, we also propose that the new deadline be more closely linked to the individual LDC's entitlement to request IPRTA under Article 67. As the completion of a priority needs assessment takes a considerable time, the deadline should be reasonable (e.g. at least 2-3 years). This requirement has several advantages, not least of which is that it would ensure that all LDCs have undertaken an internal stocktaking exercise within a reasonable period. Furthermore, this requirement would also deprive some developed countries from making the well-worn argument that they cannot provide IPRTA as the LDC has not yet prioritized or even thoroughly internalized its IP management system.

However, the situation cannot be resolved simply through the introduction of a requirement for LDCs to submit a priority needs assessment. As mentioned above, at present the scope and quality of the priority needs assessment process is varied and results of priority needs assessments differ in their scope, depth, breadth and quality. Therefore, if the TRIPS Council is to consider this proposal it must also establish minimal assessment standards and bestpractice guidelines for the conduct and submission of priority needs assessments. Another issue to be addressed is the human capital and financial resources required to complete a priority needs assessment. It is clear that many LDCs would need considerable expert advice and financial support in order to undertake a priority needs assessment, provision of which the TRIPS Council should also discuss.

In addition to the requirement to undertake and submit a priority needs assessment, we also propose that any TRIPS Council Decision granting a second extension of the transition period should include a binding provision requiring LDCs to prioritize the establishment of an adequate IP system within their national development plans (in particular within the DTIS of the EIF). While some commentators may view this requirement as unnecessarily intrusive or merely a tool for developed country monopolizers, we include this requirement for a practical reason. The reality of developmental aid is that international donors and development agencies now focus development aid only on certain areas that are also considered key priorities from a beneficiary country perspective. Failure to link the assistance requests contained in the priority needs assessment with national development plans will result in a significant decrease in the IPRTA available. In turn, this requirement is significant in the

\footnotetext{
${ }^{50}$ See supra note 1 , para.2.
} 
overall success or failure of the request. By contrast, aligning the requests contained in the priority needs assessment with the national development plans and strategies of the beneficiary country should strengthen the sustainability and ownership of cooperation projects and ensure the commitment and participation of all national stakeholders. Furthermore, as the establishment of IP laws and institutions requires a broad national consensus among various intergovernmental agencies and an abundance of other national stakeholders, it would seem that such an ambitious objective can only be achieved if it is backed by a national development plan.

\section{Applying a more gradual and development-oriented concept of TRIPS implementation for LDCs}

Taking into account that most LDCs do not have the resources to implement TRIPS in its entirety, and the legitimate question of whether this would even be useful or desirable given their limited innovative and administrative capacity, it is unrealistic to expect LDCs to establish a functioning fully-fledged IP system similar to the ones operating in developed or even middle-income developing countries. Therefore, it might be more practicable to apply a more gradual and development-oriented concept of TRIPS implementation for LDCs. ${ }^{51}$ Such an approach should focus first on reforms in those areas of IP that are essential for the LDCs' socio-economic development and that pave the way to a more stable, more innovative and more productive economy (e.g. establishing a basic but efficient system for the protection of national trademark holders). Setting a different standard for LDCs obviously creates certain asymmetries among WTO Members, which may challenge the WTO single undertaking approach, but it could be argued that continuous extensions of the transitional period do exactly the same, but without the added benefit of offering even a gradual integration into the global IP system. Additionally, the TRIPS Council Decision of 2005 already requires LDCs to comply with certain core principles such as national treatment, most-favoured nation and the so-called no roll-back provision. We thus propose that the upcoming extension be used to gradually introduce further core provisions of TRIPS that would allow LDCs to integrate smoothly into the global IP system.

\section{Identifying additional incentives for LDCs and developed countries to cooperate more actively towards LDCs' integration in the global IP system}

The low number of priority needs assessments is evidence that the current process neither offers sufficient carrots nor sticks to encourage LDCs' participation. On the one hand, the approaching deadline of the transition period does not serve as a stick because it is obvious that most LDCs do not have the capacity to make any progress towards TRIPS compliance and that all of the LDCs simply expect a further extension, and probably another one after that. It is not even a stretch of the imagination to say that some, if not most, LDCs assume that they will never have to comply with TRIPS. On the other hand, it is not easy to identify further incentives to encourage LDCs to participate in TRIPS. This is particularly the case as the Agreement does not deal with trade concessions, but merely requires the implementation

\footnotetext{
${ }^{51}$ For an overview of the concept of graduation in WTO law, see Cottier, Thomas (2006),'From Progressive Liberalization to Progressive Regulation in WTO Law', Journal of International Economic Law, (9/2006), pp. 779-821.
} 
of minimum standards, procedural requirements and the like. One option for encouraging participation would be to further improve the conditions for technology transfer for those LDCs which actively participate in the priority needs assessment process. While the TRIPS Council Decision of 2005 did not link TRIPS implementation to the provision of further incentives with regard to technology transfer, it may now be time to consider the benefits and disadvantages of such a link.

If no additional incentives to encourage LDC implementation can be found within the TRIPS itself, the WTO could also consider 'cross-incentives' for LDCs that make progress in the implementation of TRIPS through additional benefits in other sectors of trade. Similar to the strategy of cross-retaliation found in the area of WTO dispute settlement, providing additional incentives in other sectors could serve as a useful tool for encouraging LDCs to make progress in implementing TRIPS. However, such cross-incentives would involve several sectors of trade and thus would require a more comprehensive discussion within the current Doha Round of trade negotiations or in a future trade round. In the current atmosphere of the Doha Round, this is perhaps a longer term option rather than one for the immediate future.

Another, more feasible and easily operational, incentive would be to reward the efforts of those six LDCs that have already submitted priority needs assessments with swift and comprehensive IPRTA. This would provide others who may follow suit with the necessary certainty that they will also receive an appropriate level of support from developed country Members. As mentioned previously, the establishment of a coordination mechanism as well as the creation of a multilateral fund for IPRTA would play a crucial role in this process. In this regard, the efforts of the WTO Secretariat have thus far been important and should be continued. Therefore, we propose that the TRIPS Council Decision granting a second extension of the transition period should further strengthen the role of the WTO Secretariat in promoting the realization of Articles 66.1 and 67.

As mentioned in section II of this paper, the provision of IPRTA is a relatively new phenomenon in the field of development cooperation, and the track record of IPRTA in LDCs is still extremely limited. Additional research on the impact of TRIPS in LDCs and the development of best practices in IPRTA is therefore crucial. Moreover, future research should also focus on collecting empirical data about the intellectual property systems of the world's poorest countries as well as on adapting existing IP policies to serve the needs of LDCs.

\section{Conclusion}

This paper demonstrates that the vast majority of LDCs have not achieved substantial progress in the implementation of TRIPS during the latest extension of the transition period from 2005 to 2013. Developed countries have also not sufficiently supported LDC integration into the international IP system because they have failed to provide substantive and comprehensive technical and financial assistance. This lack of progress can be at least partly attributed to the shortcomings of the priority needs assessment process introduced during the last extension in 2005. Although the TRIPS Council Decision of 2005 touches upon the reciprocity between the rights and obligations of the Members under Article 66.1 and Article 67 TRIPS, each of these provisions is currently blocking the realization of the other. As a result of these deficiencies, only six of the 33 LDCs have thus far tabled individual priority 
needs assessments. The subsequent reluctance from industrialized countries to response to these initial requests for IPRTA has led to widespread frustration among developing countries about the entire exercise. Adding to the urgency of the situation is the upcoming expiration of the transitional period for implementation in the TRIPS in mid-2013. In October 2011, the LDCs requested a further extension of the transition period beyond 2013, and the Eighth Ministerial Conference decided to consider this request. The TRIPS Council now has until 1 July 2013 to agree on the duration and the conditions of a second extension.

This article argues that an unconditional second extension of the transition period for LDCs to implement TRIPS - although it seems a convenient and pragmatic move to 'buy time' in the face of disagreement among developing and developed country Members - would only lead to a further postponement of LDC's integration into the international IP system. Moreover, repeated extensions without considerable efforts to bring LDCs into compliance with TRIPS undermine the credibility of the WTO system and the organization's cherished principle of a "single undertaking". Instead, what is required is a transformation of the priority needs assessment to make the process more efficient, transparent and predictable so that it creates enough incentives for both LDCs and developed countries to engage more effectively in the integration of LDCs into the international IP system. Furthermore, we emphasize the need for improved coordination among all actors on the national, bilateral and multilateral level. As far as the funding of IPRTA is concerned the TRIPS Council has already identified the Enhanced Integrated Framework (EIF) as a potential channel of cooperation and will now require much effort as well as some additional fine-tuning to further promote this promising avenue. It is also crucial that the IP community engages in a constant dialogue with all the stakeholders involved to establish IPRTA as a credible tool for economic development cooperation.

The core of this paper is an analysis of the potential alternatives to an unconditional second extension of the transition period. In particular, we propose that further binding conditions should be introduced, which make it mandatory for all LDCs to undertake a priority needs assessment and to include the improvement of their IP system in their national development plans. We also propose the application of a more gradual and development-oriented concept of TRIPS implementation for LDCs and further recommend that the upcoming extension should be used to gradually introduce further core provisions of TRIPS that would allow LDCs to integrate smoothly into the global IP system (e.g. by establishing a basic but efficient system for the protection of national trademark holders). Finally, we try to identify additional incentives for LDCs and developed countries to engage in improving the integration of LDCs into the global IP system (e.g. to look into improving conditions for technology transfer beyond the current Article 66.2 or to provide incentives for LDCs which comply in other sectors of trade). We strongly believe that alternatives to simply offering a second extension of the transition period should be seriously discussed and adopted by the TRIPS Council in an effort to make the system more efficient, transparent and successful for all interested parties.

\section{References}

Blakeney, Michael (1996), 'Trade-Related Aspects of Intellectual Property Rights: A Concise Guide to the TRIPs Agreement', Sweet Maxwell.

Cottier, Thomas (2006),'From Progressive Liberalization to Progressive Regulation in WTO Law', 
Journal of International Economic Law, (9/2006), pp. 779-821.

Durán, Esperanza and Constantine Michalopoulos (1999), 'Intellectual Property Rights and Developing Countries in the WTO Millennium Round', 2 Journal of World Intellectual Property 6 (1999), pp. 853-874.

ICTSD (2011), 'LDC Needs Assessment under TRIPS: The ICTSD Experience (2007-2011)', Information Note No.19, International Centre for Trade and Sustainable Development, Geneva.

Kennedy, Kevin (2006), 'The 2005 TRIPS Extension for the Least-Developed Countries: A Failure of the Single Undertaking Approach?’, 40 International Lawyer (2006), pp. 683-700.

Kharas, Homi (2011), 'The Evolving International Architecture for Development Cooperation', Policy Paper 2011/11, The Brookings Institution.

Killen, Brenda and Andrew Rogerson (2010), 'Global Governance for International Development: Who's in Charge?’, OECD Development Brief, Issue 2/2010.

Leesti, Mart and Tom Pengelly (2007), 'Assessing Technical Assistance Needs for Implementing the TRIPS Agreement in LDCs, ICTSD Programme on Intellectual Property Rights and Sustainable Development LDC - A Diagnostic Toolkit', International Centre for Trade and Sustainable Development (ICTSD), Geneva, Switzerland.

Leesti, Mart (2006), 'Special Challenges for IP TA in Capacity Building in an LDC', available on: www.iprsonline.org/ictsd/docs/LDCToolkit-final.pdf.

Leirer, Wolfgang W. (1994/1995), 'Retaliatory Action in United States and European Union Trade Law: A Comparison of Section 301 of the Trade Act of 1974 and Council Regulation 2641/84', 20 North Carolina Journal of International Law \& Commercial Regulation (1994-95), pp. 41-96

Matthews, Duncan and Munoz-Tellez, Viviana (2006), 'Bilateral Technical Assistance and TRIPS: the United States, Japan and the European Communities in Comparative Perspective', 9 Journal of World Intellectual Property 6 (2006), p. 629.

Matthews, Duncan (2002), 'Globalising Intellectual Property Rights: The TRIPs Agreement', Routledge.

May, Christopher and Susan K. Sell (2005), ‘Intellectual Property Rights: A Critical History’, Lynne Rienner.

Mercurio, Bryan Christopher (forthcoming in 2013), 'TRIPS and Access to Essential Medicines', in: Prévost, Denise and Geert Van Calster (eds), 'Research Handbook on Environment, Health and the WTO', Edward Elgar.

Mercurio, Bryan Christopher (2010), 'Reconceptualising the Debate on Intellectual Property Rights and Economic Development', The Law and Development Review 3(1), pp. 65-10.

Moon, Suerie (2008), 'Does Article 66.2 Encourage Technology Transfer to LDCs? An Analysis of Country Submissions to the TRIPs Council (1999-2007)', UNCTAD/ICTSD Project on IPRs and Sustainable Development, Policy Brief Number 2 (2008).

Pengelly, Tom and Jakob Engel (forthcoming), 'Using technical and financial assistance for implementation of the TRIPS Agreement: A guidebook for LDCs', to be published by the World Trade Organization, Geneva.

Sell, Susan K. (1998), 'Power and Ideas: North-South Politics of Intellectual Property and Antitrust', State University of New York Press.

South Centre/Center for International Environmental Law (2006), 'Extension of the transition period for LDCs: flexibility to create a viable technological base or simply (a little) more time?’ IP Quarterly Update, First Quarter 2006.

Sykes, Alan O. (1992), 'Constructive Unilateral Threats in International Commercial Relations: The Limited Case for Section 301’, 23 Law \& Policy in International Business 2-3 (1992), pp. 263330. 
Trainer, Timothy P. (2008), 'Intellectual Property Enforcement: A Reality Gap (Insufficient Assistance, Ineffective Implementation)?', 8 John Marshall Review of Intellectual Property Law 1 (2008), p. 47.

World Trade Organization, Council for TRIPS Complementary Report on Technical Cooperation Activities for Least Developed Countries, Communication from Japan, 19 July 2012 (IP/C/W/572).

World Trade Organization, Council for TRIPS, Technical Cooperation Activities and Assistance for Least Developed Countries, Communication from the European Union, 20 February 2012 (IP/C/W/568).

World Trade Organization, Council for TRIPS, Minutes of Meeting on 24-25 October and 17 November 2011, 15 February 2012 (IP/C/M/67).

World Trade Organization, Council for TRIPS, Priority Needs for Technical and Financial Cooperation, Communication from Senegal, 27 June 2011 (IP/C/W/555).

World Trade Organization, Council for TRIPS, Priority Needs for Technical and Financial Cooperation, Communication from Bangladesh, 23 March 2010 (IP/C/W/546).

World Trade Organization, Council for TRIPS, Priority Needs for Technical and Financial Cooperation, Communication from Rwanda, 7 June 2010 (IP/C/W/548).

World Trade Organization, Council for TRIPS, Priority Needs for Technical and Financial Cooperation, Communication from Tanzania, 23 October 2010 (IP/C/W/552).

World Trade Organization, Council for TRIPS, Minutes of Meeting on 8-9 June 2009, 28 September 2009 (IP/C/M/60).

World Trade Organization, Council for TRIPS, Priority Needs for Technical and Financial Cooperation, Communication from Uganda, 27 May 2008 (IP/C/W/510).

World Trade Organization, Council for TRIPS, Minutes of Meeting on 25-26 and 28 October, 29 November and 6 December 2005, 31 January 2006 (IP/C/M/49).

World Trade Organization, Council for TRIPS, Extension of the transition period under Article 66.1 for least-developed country Members, Decision of the Council for TRIPS of 29 November 2005, 30 November 2005 (IP/C/40).

World Trade Organization, Council for TRIPS, Request for an extension of the transitional period under Article 66.1 of the TRIPS Agreement, Communication from the Delegation of Zambia on behalf of the Least-Developed Country Members, 21 October 2005 (IP/C/W/457).

World Trade Organization, Council for TRIPS, Extension of the transition period under Article 66.1 of the TRIPS Agreement for least-developed country Members for certain obligations with respect to pharmaceutical products, Decision of the Council for TRIPS of 27 June 2002, 1 July 2002 (IP/C/25).

World Trade Organization, WIPO and WTO Launch New Initiative to Help World's Poorest Countries Press Release, 14 June 2001 (Press/231).

World Trade Organization, Doha Declaration on the TRIPS Agreement and Public Health, 14 November 2001 (WT/MIN(01)/DEC/W/2).

World Trade Organization, Council for TRIPS, Agreement Between the World Intellectual Property Organization and the World Trade Organization, 13 December 1995 (IP/C/6).

World Trade Organization, Council for TRIPS, Minutes of Meeting on 21 September 1995, 20 October 1995 (IP/C/M/3). 